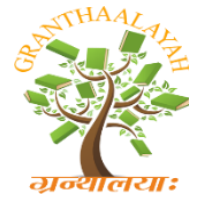

INTERNATIONAL JOURNAL OF RESEARCH GRANTHAALAYAH A knowledge Repository

Science

\title{
ANTIBACTERIAL ACTIVITY AND PHYTOCHEMICAL SCREENING OF MORINGA OLEIFERA LAM. LEAVES AND SEEDS EXTRACT ON STAPHYLOCOCCUS AUREUS
}

\author{
Garga M. A. " ${ }^{\text {, }}$, Manga S. B. ${ }^{1}$, Rabah A.B. ${ }^{1}$, Tahir H. ${ }^{1}$, Abdullahi M. ${ }^{2}$, Ahmad M. ${ }^{\text {, }}$, \\ Abdullahi H. A. ${ }^{2}$, Bako I. ${ }^{2}$, Abdurrahman S. A. ${ }^{2}$, Mukhtar U. F. ${ }^{2}$ \\ ${ }^{1}$ Usmanu Danfodiyo University, Faculty of Science, Department of Microbiology, Nigeria \\ 2 National Biotechnology Development Agency, Bioresources Development Centre, Katsina, \\ Nigeria
}

\begin{abstract}
The aim of this study was to investigate the antibacterial effect and identify the phytochemical constituents of Moringa oleifera leaves and seeds extract on Staphylococcus aureus (S. aureus) clinical isolates using agar well diffusion method. The samples were collected from the premises of Usmanu Danfodiyo University, Sokoto. The Seeds and Leaves were collected fresh. They were extracted using methanol and ethyl acetate. Various concentrations from $100 \mathrm{mg} / \mathrm{ml}$ to $500 \mathrm{mg} / \mathrm{ml}$ were prepared. The test bacteria used is Staphylococcus aureus obtained from Microbiology laboratory of the Usmanu Danfodiyo University. The bacteria were re-identified using biochemical tests. The bacterial inoculums were standardized to McFarland scale 0.5. Zone of inhibition were read after 24 hours of incubation at 370C. The results of the antibacterial study revealed that the methanolic leaves extracts at $500 \mathrm{mg} / \mathrm{ml}$ had effect on S. aureus with zone of inhibition of $20 \mathrm{~mm}$. The methanolic seed extract have effect on S. aureus with zone of inhibition of $19.5 \mathrm{~mm}$. The MIC for the leave and seed extracts for Staphylococcus aureus was $250 \mathrm{mg} / \mathrm{ml}$. The MBC was $500 \mathrm{mg} / \mathrm{ml}$. The results of the phytochemical analysis revealed the presence of flavonoid, tannins, saponins, cardiac glycosides, alkaloids, volatile oil, saponin glycosides, and glycosides but anthraquinone and steroids were absent in the extracts. The zones of inhibition showed that both the methanolic and ethyl acetate extracts at $500 \mathrm{mg} / \mathrm{ml}$ were active to all the tested bacteria. ANOVA and Duncan Multiple Mean Range test was used to analyze the data. Based on Duncan's grouping, there is significant difference between the solvents and the concentrations used.
\end{abstract}

Keywords: Antibacterial; Methanol; Ethylacetate; Extract; Leaves; Phytochemical.

Cite This Article: Garga M. A., Manga S. B., Rabah A.B., Tahir H., Abdullahi M., Ahmad M., Abdullahi H. A., Bako I., Abdurrahman S. A., and Mukhtar U. F.. (2019). "ANTIBACTERIAL ACTIVITY AND PHYTOCHEMICAL SCREENING OF MORINGA OLEIFERA LAM. LEAVES AND SEEDS EXTRACT ON STAPHYLOCOCCUS AUREUS." International Journal of Research - Granthaalayah, 7(11), 276-284. 10.29121/granthaalayah.v7.i11.2020.367. 


\section{Introduction}

Pathogenic bacteria had been considered as major cause of morbidity and mortality in humans. In recent years, multiple drug resistance among pathogenic microorganisms has been on the increase due to indiscriminate use of commercial antimicrobial drugs commonly used in the treatment of such diseases. Other reasons are the superbugs in the environment that pass resistant genes to susceptible bacteria and also the use of antibiotics in animal husbandary.

Plant families represent reservoir of effective chemotherapeutics and provide valuable sources of natural antimicrobials. Plant extracts have been used for a wide variety of purposes for thousands of years. They are used because of their antimicrobial potentials attributed to secondary metabolites they produced (Umamaheswari and Rama, 2014).

Moringa oleifera Lam. is a type of local medicinal Indian herb which has turn out to be a familiar plant in the tropical and subtropical countries. The other terms used to describe moringa are Horseradish tree, Mulangay, Mlonge, Benzolive, Drumstick tree, sajna, kelor, Saijihan, and Marango. Moringa oleifera has been identified in scientific division to have come from Kingdom: Plantae, Division: Magnoliphyta, Class: Magnoliopsida, Order: Brassicales, Family: Moringaceae, Genus: Moringa, Specie: Moringa oleifera (Ahmad et al.,2014). In Nigeria, moringa is called by many tribes as; Zogale (Hausa), Gawara (Fulani), Ewe Igbale (Yoruba), and Okwe Oyibo (Igbo) (Nwachukwu et al., 2014).

Moringa oleifera is one of the most commonly and widely used plants in its crude form in Nigeria, and many parts of the world. It has been established that every part of the plant (Leaves, Flowers, Roots, pods, and seeds) are used for the treatment of various ailments such as toothache, common cold, diarrhea, and oedema. It is used as source of foods or medications since there have been no report of any toxicity from the use of the plant. It was on the basis of this that this research was aimed at determining the antimicrobial activity and phytochemical screening of Moringa leaves and seeds for new antimicrobial principles.

\section{Materials and Methods}

\subsection{Sample Collection}

Moringa oleifera Lam. leaves and seeds are the material used in this present study. Fresh leaves and seeds were obtained from Faculty of Science (close to general Chemistry Laboratory), Jatau Bridge area, Usmanu Danfodio University, Sokoto, Sokoto State. Both the seeds and the leaves were taken to Herbarium of the Botany Unit of Biological Sciences Department, Usmanu Danfodiyo University, Sokoto, for authentication. A voucher number UDUH/ANS/0102 was obtained. The leaves were washed thoroughly with sterile distilled water in order to remove any dirt or filthy particles present on the surface. It was then shade dried for one week (7 days) and was then ground into powder using a clean mortar and pestle. It was then packaged into a clean polythene bag and was later subjected to extraction process. The seeds were first de-shelled and were shade-dried as well for a period of seven (7 days) before it was ground into fine powder. It was then packaged in a clean polythene bag and was subjected to extraction process in the laboratory (Dike-Ndudimet al., 2016). 


\subsection{Test Bacteria}

The test bacteria used was Staphylococcus aureus obtained from the Department of Microbiology of Usmanu Danfodiyo University, Sokoto. The bacteria were however confirmed by carrying out biochemical identification protocols.

\subsection{Grams Staining and Microscopy}

This was carried-out as described by Chesbrough, (2000); Oyeleke and Manga, (2008). A drop of water was placed on a clean grease free glass slide, and a colony of bacteria was taken from an overnight culture (24-hour culture) to make a thin smear. The smear was allowed to air dry and was flooded with crystal violet for 60 seconds before being washed with tap water. Lugol's iodine was added for 60 seconds and washed with tap water. It was decolorized with $95 \%$ ethanol for 15 seconds. The smear was finally flooded with safranin for 1 minutes and then washed with water and allow to air dry. It was viewed under oil immersion at (x100).

\subsection{Serological Identification of Test Isolates (Staphylococcus aureus)}

The test kit used was BD BBL Staphyloslide and was obtained from United State of America (USA). The test kit was removed from the refrigerator 10 minutes prior to use and the latex reagents were allowed to reach room temperature. It was then resuspended by inverting the dropper bottle several times. One drop of the BD BBL Staphyloslide. Test Latex was dropped into the test card circle. A sterile loop was used to transfer two colonies of the test isolate into the circle and was then mixed together and spread to cover the complete area of the circle. The card was then rocked, allowing the mixture to flow over the entire test ring area and observed for up to 20 seconds, agglutination was observed.

\subsection{Extraction of Moringa Oleifera Leaves and Seeds}

This was carried out according to the method described by Fadeyiet al., (2015) with slight modification. Four hundred grams $(400 \mathrm{~g})$ each of Moringa oleifera leaves and seeds powder were macerated separately with $1 \mathrm{~L}$ each of methanol and ethylacetate in a one liter capacity flat bottom flasks for 72 hours. The extract was filtered and concentrated using rotary evaporator at $40^{\circ} \mathrm{C}$. The extracts were placed in a clean evaporating dish and were stored in the refrigerator at $4{ }^{\circ} \mathrm{C}$ for further analysis.

\subsection{Preparation of McFarland Turbidity Standard}

McFarland Turbidity Standards are set of tubes with increasing concentration of barium sulfate suspension. Zero point five percent (0.5) McFarland Standard was prepared by mixing $0.05 \mathrm{ml}$ of $1 \%$ anhydrous barium chloride $\left(\mathrm{Bacl}_{2}\right)$ with $9.95 \mathrm{ml}$ of $1 \%$ sulfuric acid $\left(\mathrm{H}_{2} \mathrm{SO}_{4}\right)$ which forms barium sulfate precipitate (turbid solution). The tubes were tightly sealed and kept for further used. 


\subsection{Standardization of The Inoculum}

The standardization of the inoculums was carried out in accordance with the methods of Oyeleke and Manga, (2008). The isolates were sub-cultured into fresh Nutrient Agar plates and incubated at $37^{\circ} \mathrm{C}$ for 24 hours. After the incubation period, $5 \mathrm{ml}$ of sterile distilled water was placed into different universal bottles and was used to prepare the size of the inoculums. The McFarland scale of 0.5 was used which is equivalent to $1.5 \times 10^{8} \mathrm{cfu} / \mathrm{ml}$.

\subsection{Antibacterial Activity Tests of The Crude Methanolic and Ethylacetate Plant Extract}

Antibacterial screening was done using agar well diffusion method as described by Farina $e t$ al., (2014) with some slight modifications. Twenty milliliter (20ml) of sterile Mueller Hinton Agar (Hi-Media) was prepared and poured into sterile petri plates. After solidification, it was placed into the incubator at $37^{\circ} \mathrm{C}$ for 24 hours to test for media sterility. Zero point two $(0.2) \mathrm{ml}$ of the standardized inoculum was dropped onto the media using a sterile syringe and emulsified using sterilized bent glass. Five (5) uniform wells were made using $6 \mathrm{~mm}$ diameter cork-borer. Each well was filled with the various concentrations of both the methanolic and ethylacetate extracts (100, $200,300,400,500 \mathrm{mg} / \mathrm{ml}$ ) using sterile syringe respectively. They were then allowed to stand for 30 minutes, for diffusion of extracts into the medium. Ciprofloxacin $(250 \mathrm{mg})$ was used as control drug for the test isolates. The plates were incubated at $37^{\circ} \mathrm{C}$ for 24 hours. Zones of inhibitions were recorded in millimeter $(\mathrm{mm})$.

\subsection{Determination of Phytochemical Components of Methanolic and Ethylacetate Crude Extracts}

The phytochemical screening of the extracts was carried out according to the methods described by Treases and Evans (1989) and Harbone (1998). The component analyzed were flavonoid, tannin, saponin, glycoside, alkaloid, cardiac glycoside, steroids, saponin glycoside, balsams, anthraquinones, and volatile oils.

\subsubsection{Test for Flavonoid}

Three $(3 \mathrm{ml})$ aliquot of the filtrate and $1 \mathrm{ml}$ of $10 \% \mathrm{NaOH}$ sodium hydroxide were mixed, if a yellow colour is developed, it indicates the presence of flavonoid compounds (Harbone, 1998).

\subsubsection{Tests for Tannins}

Ferric chloride solution $5 \%$ ferric chloride solution was added to $3 \mathrm{ml}$ of the extract and the coloured produced is noted. Condensed tannins usually give a dark green colour; hydrolysable tannins give blue-black colour (Trease and Evans, 1989, and Harbone, 1998,).

\subsubsection{Tests for Saponin}

Five milliliter $(5 \mathrm{ml})$ of the extract was placed in a test tube with $5 \mathrm{ml}$ of water and shaked strongly. The whole tube will be filled front that lasts for several minutes (Harbone, 1998) which indicates the presence of saponin. 


\subsubsection{Tests for Glycosides}

Two point five $(2.5 \mathrm{ml})$ of $50 \% \mathrm{H}_{2} \mathrm{SO}_{4}$ was added to $5 \mathrm{~cm}^{3}$ of the extract in a test tube. Cool and neutralize with $10 \% \mathrm{NaOH}, 5 \mathrm{ml}$ of Fehling's solution was added and the mixture was boiled. A brick-red precipitate was observed which indicate the presence of glycosides (Harbone, 1998).

\subsubsection{Tests for Alkaloids}

About $2 \mathrm{ml}$ of each extract was stirred with $2 \mathrm{ml}$ of $10 \%$ aqueuos hydrochloric acid. $1 \mathrm{ml}$ was treated with a few drops of Wagners reagent and the second $1 \mathrm{ml}$ portion was treated similarly with Mayers reagent. Turbidity or precipitation with either of these reagents was taken as preliminary evidence for the presence of alkaloids (Harbone, 1998).

\subsubsection{Test for Cardiac Glycosides (Keller-Killiani’s test)}

To $5 \mathrm{ml}$ of the extract, $2 \mathrm{ml}$ of $3.5 \%$ ferric chloride solution was added and allowed to stand for one minutes. One $\mathrm{ml}$ of concentrated $\mathrm{H}_{2} \mathrm{SO}_{4}$ was carefully poured down the wall of the tube so as to form a lower layer. A reddish brown ring in the interface indicates the presence cardiac glycoside (Harborne, 1998).

\subsubsection{Tests for Steroids (Salkowski)}

This was carried out according to the method of Harbone, (1998), 0.5g of the extract was dissolved in $2 \mathrm{ml}$ of chloroform. Two milliliter $(2 \mathrm{ml})$ of sulphuric acid was carefully added to form lower layer. A reddish - brown colour at the interface indicate the presence of a steroidal ring.

\subsubsection{Test for Saponin glycosides}

To $2.5 \mathrm{ml}$ of the extract mixed with $2.5 \mathrm{ml}$ Fehling's solution A and B, a bluish green precipitate showed the presence of saponin glycosides (Treases and Evans, 1989).

\subsubsection{Test for Anthraquinones}

Zero point five $(0.5 \mathrm{~g})$ of each plant extract was shaken with $10 \mathrm{ml}$ benzene, and $5 \mathrm{ml}$ of $10 \%$ ammonia solution was added. The mixture was shaken and the presence of a pink, red, or violet colour in the ammoniacal (lower) phase indicates the presence of anthraquinones (Evans, 1980).

\subsubsection{Tests for Volatile Oils}

One milliliter $(1 \mathrm{ml})$ of the fraction was mixed with diluted $\mathrm{HCl}$. A white precipitate was formed which indicated the presence of volatile oils (Evans, 1998).

\section{Results and Discussion}

The results of the antibacterial activity of Moringa oleifera leaves and seeds extract on Staphylococcus aureus is presented in Table 1 below. The result reveals that both methanolic and 
ethylacetate crude extracts of the leaf and seed of Moringa oleifera were active against Staphylococcus aureus at various concentrations. At concentrations of $100 \mathrm{mg} / \mathrm{ml}$ and $200 \mathrm{mg} / \mathrm{ml}$, all the test organisms were not susceptible to all the extracts. However, all the tests isolates were susceptible to all the crude extracts at $500 \mathrm{mg} / \mathrm{ml}$ which is the highest concentration with the highest zone of inhibition of $20 \mathrm{~mm}$ on Staphylococcus aureus. The tests organisms showed some level of resistance against the extracts at $300 \mathrm{mg} / \mathrm{ml}$ and $400 \mathrm{mg} / \mathrm{ml}$ concentrations.

Table 1: Antibacterial activity of Moringa oleifera leaves and seeds crude extracts against the test bacteria

\begin{tabular}{|l|cc|cc|}
\hline \multicolumn{4}{|c|}{ Zones of inhibition in (mm)/ tested against Staphylococcus aureus } \\
\hline Concentration of extracts (mg/ml) & \multicolumn{2}{|c|}{ Leaves } & \multicolumn{2}{c|}{$\begin{array}{c}\text { Seeds } \\
\text { Methanol Ethylacete }\end{array}$} \\
& 0.0 & 0.0 & 0.0 & 0.0 \\
\hline 100 & 0.0 & 0.0 & 0.0 & 0.0 \\
\hline 200 & $15 \pm 0.0$ & 0.0 & $14 \pm 1.4$ & 0.0 \\
\hline 300 & $18.5 \pm 0.7$ & 0.0 & $16 \pm 1.4$ & $16 \pm 0.0$ \\
\hline 400 & $20 \pm 1.4$ & $13 \pm 1.4$ & $19.5 \pm 0.7$ & $18 \pm 1.4$ \\
\hline 500 & 27 & 27 & 28 & 27 \\
\hline Control Drug (Ciprofloxacin) & & & & \\
\hline
\end{tabular}

Key: STA= Staphylococcus aureus

The results of the phytochemical screening of the crude extracts of Moringa oleifera leaves and seeds are presented in Table 2 below. The result reveals the presence of flavonoids, tannins, saponins, cardiac glycosides, alkaloids, volatile oil, saponin glycosides and glycosides in crude methanolic leave extract, while steroids and anthraquinone were absent in both the leaves and seeds. Methanolic leaves extract has shown to contain in abundance, more of the bioactive constituents when compared to the methanolic seeds extract shown in the Table 2 while in the ethylacetate leave extract despite the absence of some of the components, still had saponins more in abundance as compared to the seed ethylacetate extract.

Table 2: Phytochemical screening of the leaves and seeds of methanolic and ethylacetate extracts of Moringa oleifara

\begin{tabular}{|l|c|c|c|c|}
\hline \multirow{2}{*}{ Bioactive compounds } & \multicolumn{4}{|c|}{ Plant parts } \\
\cline { 2 - 5 } & \multicolumn{3}{|c|}{ Leaves } & \multicolumn{2}{c|}{ Seeds } \\
\cline { 2 - 5 } & Methanol & Ethylacetate & Methanol & Ethylacetate \\
\hline Flavonoids & ++ & + & + & + \\
\hline Tannins & + & + & + & + \\
\hline Saponnins & ++ & ++ & + & + \\
\hline Cardiac glycosides & + & + & ++ & - \\
\hline Steroids & - & - & - & - \\
\hline Alkaloids & +++ & - & + & + \\
\hline Volatile oil & ++ & - & - & + \\
\hline Anthraquinones & - & - & - & - \\
\hline Saponin glycosides & +++ & - & - & - \\
\hline Glycosides & ++ & + & ++ & + \\
\hline
\end{tabular}

Key: + = slightly abundant, ++ = moderately abundant, +++ = highly abundant, - = absent 


\section{Discussion}

Crude antibacterial activity of methanolic and ethylacetate Moringa leaves and seeds extract in this study showed that at concentration of $100 \mathrm{mg} / \mathrm{ml}$ and $200 \mathrm{mg} / \mathrm{ml}$, all the test bacterial isolates were not susceptible to all the extracts. This suggest that susceptibility of all the test bacteria to both methanol and ethylacetate extract starts at concentration of $300 \mathrm{mg} / \mathrm{ml}$ through $500 \mathrm{mg} / \mathrm{ml}$ which showed that the higher the concentration of all the extract, the higher the antimicrobial activity, thus, this exhibit the concentration dependent activity of the test substance. This is similar with a concentration dependent nature of antibiotics in which the rate of bacterial eradication rises with increase in concentration of the drug or plant substance. This finding is in agreement with the work of Akinyeye et al., (2014) which showed that all the test bacteria were not susceptible to all the leaves and seeds extracts of moringa plant at a concentration of $260 \mathrm{mg} / \mathrm{ml}$ and $270 \mathrm{mg} / \mathrm{ml}$ moringa leaves and $234.71 \mathrm{mg} / \mathrm{ml}$ and $367 \mathrm{mg} / \mathrm{ml}$ seed extracts. The highest zone of inhibition of Staphylococcus aureus in this study was found to be $20 \mathrm{~mm}$ at $500 \mathrm{mg} / \mathrm{ml}$ concentration in both the leaves and seeds extract. This result is in line with the findings of Emmanuel et al. (2014); and Namrata et al. (2014) which showed the highest zones of inhibition of $14.5 \mathrm{~mm}$ and $15 \mathrm{~mm}$ in both leaves and seeds methanol and ethylacetate extracts respectively. The result obtained for the concentrations of the extract $300 \mathrm{mg} / \mathrm{ml}, 400 \mathrm{mg} / \mathrm{ml}$ and $500 \mathrm{mg} / \mathrm{ml}$ at $\mathrm{P}<0.05$ level of significance based on Duncan's multiple mean range test showed that there is a significant differences between the concentrations $(300 \mathrm{mg} / \mathrm{ml}, 400 \mathrm{mg} / \mathrm{ml}$, and $500 \mathrm{mg} / \mathrm{ml}$ ) and the solvents used. This implies that the extracts showed a great concentration dependent inhibition, as it was observed that at concentration of $100 \mathrm{mg} / \mathrm{ml}$ and $200 \mathrm{mg} / \mathrm{ml}$, no zone of inhibition was observed, but at higher concentrations $(300,400$, and $500 \mathrm{mg} / \mathrm{ml})$, inhibition zones was observed and recorded.

The results of phytochemical screening of the leaves and seeds extracts revealed the presence of flavonoid, alkaloids, glycosides, volatile oil, cardiac glycosides, saponin glycosides, tannins, and saponins including the leaves methanol: acetone column fraction. The presence of flavonoids coincides with the work of Josephine et al., (2010) which showed flavonoid to be effective antimicrobial substances in vitro against a wide array of microorganisms by inhibiting membrane bound enzymes.

The presence of alkaloids in this study is similar with the findings of Akinyeye et al. (2014) which demonstrated that alkaloids possess both antibacterial and anti-diabetic properties. The presence of tannins correlates well with the findings of Luet al., (2004) that tannins possess antibacterial, antiviral, and anti-parasitic substances. The presence of cardiac glycosides also coincides with the report of Auwal et al. (2013) that aqueous Moringa seed extract was found to have antibacterial potentials on many pathogenic bacteria. Cardiac glycosides was found to be absent in the seed ethylacetate extract. This is similar with the findings of Roopalatha and Vijay (2013) which showed the absence of cardiac glycosides in Moringa leaves aqueous extract and also the work of Anthonia, (2012) who reported the absence of cardiac glycosides in ethylacetate extract of Moringa oleifera leaves. Steroids and anthraquinones were absent in all the extracts including the active column fraction. This is in line with the findings of Anthonia, (2012) and Olufunmilayo et al., (2012) which showed the absence of steroid and anthraquinone respectively. Absent of alkaloids in the ethylacetate extract is in consornance with the report of Bukaret al., (2010) which showed the absence of alkaloids. Volatile oil appeared to be absent in both Moringa leaves and seeds. This is similar with the work of Vinoth et al., (2012) that showed absence of volatile oil in 
Moringa plant. The presence of saponin glycosides is in concordance with the work of Fowoyo and Oladoja, (2015) which showed the presence of saponin glycosides in both seed and leaves of Moringa while the work of Abdulkadir et al., (2015) showed the absence of saponin glycosides in the root extract of Moringa oleifera plant. The implication of these findings is that bioactive compounds are believed to be responsible for the observed antibacterial activity of the plant extracts.

\section{Conclusion}

The study showed that the leaves and seeds of Moringa oleifera Lam. have antibacterial effects on the test bacterial isolates by producing zones of inhibition of $20 \mathrm{~mm}$ for both the leaves and seeds extracts at a concentration of $500 \mathrm{mg} / \mathrm{ml}$. At the concentration of $100 \mathrm{mg} / \mathrm{ml}$ and $200 \mathrm{mg} / \mathrm{ml}$, both methanol and ethyl acetate extracts shows no activity against the test bacteria. The phytochemical screening revealed lots of phytochemicals such as flavonoids, tannins, saponins, cardiadiac glycosides, alkaloids, volatile oil, saponin glycosides, and glycosides in the crude extracts.

\section{References}

[1] Akinyeye, A.J., Solanke E.O., and Adebiyi, I.O. (2014). Phytochemical and Antimicrobial Evaluation of Leaf and Seed of Moringa oleifera Extracts, International Journal of Research in Medical and Health Sciences, 4(6): 1-10

[2] Abdulkadir, I.S., Nasir, I.A., Sofowora A., Yahaya F., and Ahmad A.A., (2015). Phytochemical Screening and Antimicrobial Activities of Ethanolic Extracts of Moriga oleifera lam. On Isolates of Some Pathogens, Journal of Applied Pharmacy, 7: 203

[3] Anthonia, O.O. (2012). Evaluation of Antimicrobial Properties and Nutritional Potentials of Moringa oleifera Lam. Leaf in South-western Nigeria, Malaysian Journal of Microbiology, 8(2): 59-67

[4] Auwal, M.S., TijjaniA.M.,Sadiq, M.A., Saka, S., Mairiga, I.A., Suaibu A., Adawaren, E., and Gulani, I.A. (2013). Antibacterial and Haematological Activity of Moringa oleifera Aqueous Seed Extracts in Wister Albino Rats, Sokoto Journal of Veterinary Sciences, 11(1): 28-37

[5] Ahmad Faizal, A.R., Muhammad, D.I., and Saie, B.K. (2014). Health Benefits of Moringa oleifara, Asian pacific Journal of Cancer Prevention, 15(20), 8571-8576

[6] Bukar, A., Uba, A., and Oyeyi, T.I. (2010). Antimicrobial Profile of Moringa oleifera Lam. Extracts Against Some Food-borne Microorganisms, Bayero Journal of Pure and Applied Sciences, 3: 4348

[7] Cheesbrough, M. (2000). Fungal Pathogens, District Laboratory Practice for Tropical Countries. Cambridge University Press, 235-47

[8] Emmanuel, S.A., Olajide, O.O., Abubakar, S., Idowu I.D., Orishadipe, A.T., and Thomas, S.A. (2014). Phytochemical and Antimicrobial Studies of Methanol, Ethylacetate, and Aqueous Extracts of Moringa oleifera Lam. Seeds, American Journal of Ethnomedicine, 1(5): 346-354

[9] Harbone, J.B. (1998). Phytochemical Methods: A Guide to Modern Technique of Plant Analysis. Chapman and Hall, London.

[10] Farina, M., Preeti, B., and Neelam, P. (2014). Phytochemical Evaluation, antimicrobial activity, and determination of bioactive components from leaves of Aegle marmelos, Journal of Biomedical Research International, 2014 (2014): 1-11

[11] Fadeyi, A., Raheem, R.A., Bello, M.K., Njan, A.A., Olatunji, L.A., Afolabi, S.O., and Olorundare, O.E. (2015). Antibacterial Activity of Crude Extracts of Moringa oleifera Lam. Leaf (Moringacea), Nigerian Journal of Pharmaceutical Sciences, 14(1): 1-7 
[12] Josephine, N.K., Gabriel, S.B., Lonzy, O.J.O., and Jasper, W.O. (2010). Phytochemicals and uses of Moringa oleifera leaves in Uganda rural communities, Journal of Medicinal Plants Research, 4(9): 753-757

[13] Lu, L., Liu, S., Jiang, S., and Wu, G. (2004). "Tannin Inhibit HIV-1 Entry by Targeting gp41”, Journal of Acta-Pharmacology, 25: 8-213

[14] Namrata, P., Dipika, N., Surabhi, A., and Pandey, A. (2014). In vitro Evaluation of Antibacterial Properties of Moringa oleifera, Dalbergia sissoo, and Alstonia scholaris, Journal of Biology, Agriculture, and Healthcare, 4 (15): 54-62

[15] Nwachukwu, N., Ibiam, U.A., Igwenyi, I.O., Offor C.E., and Orji, U.A. (2014). Comparative Gas chromatography-Mass spectrometry (GC-MS) Analysis of Chemical Compounds of Moringa oleifera Leaves and Seeds from Abakaliki, Nigeria, Journal of Life Sciences and Technology, 24: 73-79

[16] Olufunmilayo, E.A., Kolapo, A.L., and Folarin A.O., (2012). Moringa oleifera Lam. (Moringaceae) Grown in Nigeria: In vitro Antistickling Activity on Deoxygenated Erythrocyte cells, Journal of Pharmacy and Bioalllied Sciences,4(2): 118-122

[17] Roopalatha, U.C., and Vijay M.N. (2013). Phytochemical Analysis of Successive Extracts of the leaves of Moringa oleifera Lam. International Journal of Pharmacy and pharmaceutical Sciences,5(3): 629- 634

[18] Trease, G.E. and Evans, W.C. (1989). Pharmacology, 11thEdition, Bailliere Tindal Ltd, London: $60-75$

[19] Umamaheswari, B.U. and Rama, R. (2014). Isolation of CSMBs for the Biodegradation of Recalcitrant Pollutants, International Journal of Current Microbiology and Applied Sciences, 3(11): 833-848

[20] Vinoth, B.M., and Balamurugan, S. (2012). Phytochemical Analysis and Antibacterial Activity of Moringa oleifera, International Journal of Research in Biological Sciences, 2(3):98-102

[21] Oyeleke, S.B. and Manga, S.B. (2008). Essentials of Laboratory Practicals in Microbiology. Niger,TOBEST PUBLISHER,93-99

[22] Fowoyo, P. T., and Oladoja, E.O. (2015). Phytochemical Screening, Nutritional Composition and Antimicrobial Activity of Moringa oleifera Seed and leaf Extracts against selected Gastrointestinal Pathogens, Journal of Pharmacy and Biological Sciences, 10 (6): 116-124

\footnotetext{
*Corresponding author.

E-mail address: muhammadadamugarga@gmail.com
} 